\section{Phreatic Tendencies of Exotic Grasses and Residual Species as Indicated by Radioisotope Absorption ${ }^{1}$}

\section{J. H. ROBERTSON, CLIFTON BLINCOE, AND CLARK TORELL}

Range Ecologist, Division of Renewable Natural Resources; Research Chemist, Department of Biochemistry; and Superintendent, Knoll Creek Field Laboratory,

\author{
University of Nevada, Reno.
}

\section{Highlight}

Rooting habits with respect to the capillary moisture zone above the watertable were studied by two methods: (1) absorption and translocation of radioactive isotopes and (2) direct observation of trench walls. Isotopes used were ${ }^{131} \mathrm{I},{ }^{99} \mathrm{Mo},{ }^{51} \mathrm{Cr}$ and ${ }^{75} \mathrm{Se}$. In general, grasses appeared to absorb more actively in spring than in fall, and more from midlevel of the capillary zone than from the top or bottom. The highest activity was in foliage of intermediate wheatgrass which accumulated ${ }^{75}$ Se from the watertable. While some injections resulted in no detected absorption, all grasses showed ability to pick up radioactivity at various levels in the capillary zone.

The purpose of this study was to learn more about the root function of exotic grasses with particular attention to the zone of soil constantly replenished by moisture from the watertable.

Abuse of watersheds has induced streambed erosion which has drained many native "stringer" meadows in the basin ranges of the

${ }^{1}$ Contribution from the Agricultural Experiment Station, University of Nevada, Journal Series No. 195. This study was supported by Hatch Projects 104 and 602. Received July 21, 1971. lary moisture within reach of big sagebrush and rubber rabbitbrush (Chrysothamnus nauseosus). In many places the roots of drought enduring forage grasses can penetrate to this zone.

Cover, height, and density of shrubs along with composition of the understory vegetation are useful ground water indicators. Big sagebrush 7 to 9 feet tall is common over watertables of 4 to 6 feet. Such brush is totally unpalatable and wasteful.

Conversion to grass cover by burning and secding has bcen demonstrated over several years at Knoll Creek Field Laboratory, 40 miles North of Wells, Nevada. Highly productive pastures resulted. However, best choice of grasses for these sites is not clcar.

Answers may be found below Intermountain Region of Western U.S.A. As a result of lowered watertable, hydrophytes such as sedges (Carex spp.) rushes (Juncus spp.), blue flag (Iris missouriensis), arrowgrass (Triglochin maritima), rose (Rosa woodsii) and others have disappeared. Lack of competition and improved aeration have encouraged big sagebrush (Artemisia tridentata) to invade and poverty weed (Iva axillaris) to increase.

Low hydraulic conductivity with slow drainage toward the gully tends to maintain a zone of capil- the surface. After studying the rhythmic duirnal and annual fluctuations of the watertable under brush it was found that ground water at 2.5 to 10 feet, capillary rises of 3 to 4 feet, annual variations of one foot and daily variations of one inch in the watertable were common at Knoll Creek.

The importance of the root system to soil-plant-water relationships has been emphasized by many ecologists, including Pavlychenko (1942) and Weaver (1926). These 
Table 1. Moisture (\%) in capillary zones of four trenches by gravimetric method, depth (inches) of sample and observed maximum root depths (inches). Average of 2 replications, June 10, 1971.

\begin{tabular}{|c|c|c|c|c|c|c|c|c|}
\hline \multirow[b]{3}{*}{$\begin{array}{l}\text { Trench } \\
\text { No. }\end{array}$} & \multicolumn{6}{|c|}{ Position in capillary moisture zone } & \multirow[b]{3}{*}{$\begin{array}{l}\text { Maximum } \\
\text { root depth }\end{array}$} & \multirow[b]{3}{*}{ Species $^{1}$} \\
\hline & \multicolumn{2}{|c|}{ Top } & \multicolumn{2}{|c|}{ Middle } & \multicolumn{2}{|c|}{ Bottom } & & \\
\hline & Moisture & $\begin{array}{l}\text { Sample } \\
\text { depth }\end{array}$ & Moisture & $\begin{array}{c}\text { Samplc } \\
\text { depth }\end{array}$ & Moisture & $\begin{array}{c}\text { Sample } \\
\text { depth }\end{array}$ & & \\
\hline 4 & 32.0 & 28 & 46.0 & 54 & 55.0 & 72 & 74 & Desert wheatgrass \\
\hline 12 & 39.0 & 33 & 34.5 & 49 & 50.5 & 60 & 49 & Russian wildrye \\
\hline 13 & 47.0 & 35 & 39.5 & 47 & 54.5 & 56 & 69 & Basin wildrye \\
\hline 14 & 38.5 & 57 & 40.5 & 95 & 52.0 & 124 & 110 & Mixture \\
\hline
\end{tabular}

${ }^{1}$ The three species named in order are Agropyron desertorum, Elymus junceus and E. cinereus.

men observed root systems in place after excavation. They judged the working depth to be the zone of most profuse branching. Further, Weaver found evidence that absorption of water and nutrients was controlled in part by phenology, and not entirely by availability. Nedrow (1937) determined levels of active absorption by supplying water at controlled levels and observing recovery from drought by the shoots of several prairie species.

More recently a few ecologists have applied non-toxic radioisotopes at specific locations among plant roots and drawn conclusion regarding root distribution on the evidence of gamma or beta ray emissions from either inplace or harvested foliage. Among workers using this method are Burton et al. (1954), Mathis et al. (1965), Price (1965) and Eckert and Blincoe (1970).

\section{Procedure}

Big sagebrush and rubber rabbitbrush were replaced on about 300 acres of Knoll Creek Valley land 40 miles north of Wells, Nevada, between 1960 and 1965. Numerous plots and pastures were established, both as pure stands and as mixtures of species named in tables $1,2,3,6$ and 7 .

1965.-Six trenches were excavated below the watertable in 4 grass plots sown in 1960 and 2 in big sagebrush. The soil is Knoll Creek loam, imperfectly drained phase; the slope is less than $2 \%$. Walls of the trenches were examined by the direct method as described by Weaver (1926). Following inspection, the trenches were covered by planks and earth mounds. Six trenches were suitable in June, 1968 for further use. Trench No. 4 (Table 1) is typical of the area.

Spring 1968.-Ten to 15 microcuries of ${ }^{131} \mathrm{I},{ }^{99} \mathrm{Mo}$ and ${ }^{51} \mathrm{Cr}$ were injected into the vertical walls of each trench at the top, middle and bottom, respectively, of the capillary zone. Injections were completed between 8:30 a.m. and 12:00 p.m. on June 12. Forage samples were taken at 6, 24 and 48 hours after injection. They consisted of 8 leafy shoots, 4 from each of 2 grass tufts nearest the trench side, or nearby rhizomatous shoots. Laboratory analysis was begun on June 17. One- to tengram samples were placed in paper envelopes and the radioactivity detcrmined by multichannel gammaray spectrometry as described in Eckert and Blincoe (1970). The air-dried weight was later determined. The standard deviations of the radioactivity measurements were $\pm 10 \%$ or less.

Fall 1968.-Three new trenches were made by backhoe in Knoll Creek loam soil, drained phase, slope more than $2 \%$. The same three isotopes were injected at the 3 levels on September 28. Three injections spaced at 2 feet and 7 spaced at one foot intervals were done in opposite walls of each trench.

A strong tendency toward increasing clay content with depth was noted. In one trench the ex- posed wall was described by Dr. Fredrick Peterson as follows: Ap, 0-5 inches disturbed light sandy loam; $\mathrm{Al}^{\mathrm{b}}$, 5-22 inches, grading downward from very fine sandy loam to silt loam, massive, friable when moist, hard when dry, sticky and plastic when wet; weak to moderate subangular blocky structure; few fine continuous pores to $6 \mathrm{ft}$. Trenches 12, 13 and 14 are in this area (Table 1).

One day after injection, soil samples were taken by use of a tube pressed 6 inches into the trench wall at points 3 and 6 inches above and below the levels of injection. The purpose was to detect vertical movement of the tracers.

Foliage samples were collected from 4 exotic and 3 native species nearest the trenches 24 and 48 hours after placement of the tracer elements.

Spring 1970.-A different technique was devised for placing tagged elements on June 2. Nine threeinch auger holes barely short of the watertable were drilled near 3 or more plant species. Each hole was segmented and plugged slightly above water, midway, and at the top of the capillary zone. Prior to plugging, $6 \mathrm{ml}$ of solution containing 100 microcuries of an isotope were deposited through a plastic tube at each level. About 15 minutes were allowed for lateral diffusion before building the next level in the hole. Forage samples were collected 1, 3 and 17 days after placement of the isotopes and analyzed for ${ }^{131} \mathrm{I},{ }^{99} \mathrm{Mo}$ and ${ }^{51} \mathrm{Cr}$. 
Table 2. Depths (feet) of root penetration in relation to the capillary moisture zone at Knoll Creek in 1965 as seen by direct inspection in trenches.

\begin{tabular}{lccc}
\hline \hline \multirow{2}{*}{\multicolumn{1}{c}{ Vegetation near trench }} & \multicolumn{3}{c}{ Depth } \\
\cline { 2 - 4 } & Capillary zone & Watertable & Rootlets \\
\hline Crested wheatgrass & 2.3 & 3.6 & 3.3 \\
Desert wheatgrass & 2.5 & 5.0 & 3.5 \\
Siberian wheatgrass (A. sibiricum) & 2.5 & 5.0 & 2.5 \\
Russian wildrye & 3.1 & 5.5 & 3.1 \\
Basin wildrye & 2.5 & 5.0 & 5.0 \\
Big sagebrush & 3.4 & 4.3 & 4.3 \\
Big sagebrush & 2.3 & 3.4 & 3.4 \\
Aster (Aster sp.) & 3.1 & 5.5 & 4.1 \\
Aster & 2.5 & 5.0 & 3.7 \\
Povcrty weed & 2.8 & 6.6 & 6.6 \\
\hline
\end{tabular}

Fall 1970.-The fourth series of isotopes was placed at desired levels with respect to the capillary moisture zone on September 2. The technique used was similar to that described by Price (1965). Smooth seamless metal tubes with close fitting rods $1 \mathrm{~cm}$ in diameter inserted were jacked into the ground to the desired depth near species whose absorption levels were to be studied. A 2-inch round-headed carriage bolt closing the bottom of the pipe was partially ejected by tapping the rod after the tube was in place. The rod was extracted and replaced by a plastic tube through which $100 \mathrm{ml}$ of radioactive solution were poured. This method seemed better suited to our soil than the method dcscribed by Woods, 1969. Twohundred microcuries of ${ }^{51} \mathrm{Cr}$ and ${ }^{75} \mathrm{Se}$ were used both alone and together. At each location, isotopes were again placed at the top, middle and bottom of the capillary zone.

Foliage of 7 species was sampled at 3 days and at 11 weeks.

\section{Results and Discussion}

1965.-Exploration for ends of rootlets in the capillary zones of 7 trenches yielded measurements for penetration by 8 species, 4 of which were seeded exotics. Roots of pubescent wheatgrass (Agropyron trichophorum) were possibly mixcd with those of Aster, so are not re- ported. Wide variation in abundance and depth of rootlets was observed. Native species appeared to approach the ground water closer than did the exotic dryland grasses. These variations are shown in Table 2.

Lack of control in sampling makes tests of significance of mean differences of doubtful validity.

Spring 1968.-Radioactivity of the foliage samples indicated the tracer elements were absorbed about equally from the middle and top of the zone of capillary moisture. Pubescent wheatgrass absorption appeared to diminish uniformly as depth increased. Only crested wheatgrass (Agropyron cristatum) absorbed more from the bottom than from the top. Desert wheatgrass registered the highest from middle and bottom zones, and Basin wildrye the highest from the

Table 3. Relative absorption of tracer elements by grasses from three positions in the capillary zone during spring growth, 1968. Radioactivities are ranked 1-3 in decreasing order for each grass.

\begin{tabular}{lcccc}
\hline \hline & & \multicolumn{3}{c}{ Position Injected } \\
\cline { 3 - 5 } \multicolumn{1}{c}{ Species } & No. of comparisons & $\begin{array}{c}{ }^{99} \mathrm{Mo} \\
\text { Top }\end{array}$ & $\begin{array}{c}{ }^{131} \mathrm{I} \\
\text { Middle }\end{array}$ & $\begin{array}{c}{ }^{51} \mathbf{C r} \\
\text { Bottom }\end{array}$ \\
\hline Crested wheatgrass & 7 & 3 & 1 & 2 \\
Desert wheatgrass & 12 & 1 & 3 & 2 \\
Siberian wheatgrass & 7 & 2 & 1 & 3 \\
Pubescent wheatgrass & 7 & 1 & 2 & 3 \\
Russian wildrye & 7 & 2 & 1 & 3 \\
Basin wildrye & 6 & 1 & 3 & 2 \\
\hline
\end{tabular}
wheatgrass was a high absorber top and bottom. In one or more instances each species absorbed from the watertable, which was at 6.6 feet under desert wheatgrass.

Relative amounts of tracer absorbed are indicated by ranks in Table 3. The ranks are based upon the average reading from all the opportunities presented for absorption by sampled plants on both sides of 6 trenches.

Analysis indicated that the 24hour absorption period picked up more radioactivity than did the 6 or 48-hour periods (Table 4). ${ }^{131} \mathrm{I}$ was absorbed from midzone by all 6 species, but tracers from the top and bottom of the capillary zone were detected from 6 of 7 points. Twenty-four hour absorption registered uptake from top and bottom ( ${ }^{99} \mathrm{Mo}$ and ${ }^{51} \mathrm{Cr}$ ), at 7 and 5 points respectively, of the 7 available (Table 5).

Fall 1968.-The 24-hour absorption period again produced higher mean activity in the shoots than did the 48-hour period. Poverty weed and sagebrush were scarcely exceeded by the wildryes in picking up ${ }^{51} \mathrm{Cr}$ from 80 inches in saturated soil at the bottom of the capillary zone. All species but poverty weed absorbed more from the top than from either other level. Pubescent from the top while failing to pick up ${ }^{51} \mathrm{Cr}$ at the bottom. Sagebrush ranked second highest in absorption from the top, absorbing well at all levels. Relative activities of 7 species are shown in Table 6 . 
Table 4. Relative absorption of tagged elements (Counts/minute/gram) means of 2 replications and ratios after absorption periods of 6,24 , and 48 hours, June 1968.

\begin{tabular}{|c|c|c|c|c|c|c|c|c|c|}
\hline & \multicolumn{9}{|c|}{ Period in hours } \\
\hline & \multicolumn{3}{|c|}{6} & \multicolumn{3}{|c|}{24} & \multicolumn{3}{|c|}{48} \\
\hline & $\begin{array}{l}{ }^{99} \mathrm{Mo} \\
\text { Top }\end{array}$ & $\begin{array}{c}{ }^{131} \mathbf{I} \\
\text { Middlc }\end{array}$ & $\begin{array}{l}{ }^{51} \mathrm{Cr} \\
\text { Bottom }\end{array}$ & $\begin{array}{l}{ }^{99} \mathrm{Mo} \\
\text { Top }\end{array}$ & $\begin{array}{c}{ }^{131} \mathbf{I} \\
\text { Middle }\end{array}$ & $\begin{array}{r}{ }^{51} \mathrm{Cr} \\
\text { Bottom }\end{array}$ & $\begin{array}{l}\text { Mo } \\
\text { Top }\end{array}$ & ${ }_{\text {Middlc }}^{131}$ & $\begin{array}{c}{ }^{51} \mathrm{Cr} \\
\text { Bottom }\end{array}$ \\
\hline $\mathrm{cpm} / \mathrm{g}$ & 5.5 & 23.8 & 1.7 & 9.0 & 22.9 & 3.9 & 3.4 & 2.5 & 1.0 \\
\hline Ratios & 3 & 14 & I & 2 & 6 & 1 & 3 & 2 & I \\
\hline
\end{tabular}

Seven injections per trench wall did not produce more $\mathrm{cpm} / \mathrm{g}$ of sample than did 3 injections.

One replication of desert wheatgrass was 100 times as active from top absorption as from the middle. Apparently a "main line" injection was responsible, i.e., accidental injection into a root. This datum is omitted from all averages.

Soil sample analysis after 2 days gave evidence of movement of the tracer element. ${ }^{131}$ I was most active and ${ }^{99} \mathrm{Mo}$ least active at 3 inches above levels of injection. ${ }^{131} \mathrm{I}$ activity appeared in samples 3 inches above and 17 inches below the point of injection. ${ }^{51} \mathrm{Cr}$ and ${ }^{99} \mathrm{Mo}$ were detected, 24 inches and 11 inches respectively, above the point of injection in only one sample. This is attributed to translocation. "Mineral nutrients may enter growing organs through either or both of the vascular tissues" (Bonner and Galston, 1952).

Spring 1970.-The technique employed in June 1970 to place the same 3 tracers at three levels was less successful than use of the trench walls in 1968. One day proved

to be the best absorption period. Among 7 species, only Russian wildrye and Canada vetch (Astragalus canadensis) were radioactive after 17 days. Canada vetch exceeded the six grasses in absorption at all depths and periods. Siberian wheatgrass failed to absorb under this method while desert wheatgrass responded at all depths at both of its location. Peak activities in all species were derived from the top of the capillary zones at 16 to 30 inches depth.

The range in radioactivity among species, locations and depths varied from 200 at the midzone by Canada vetch to $2 \mathrm{cpm} / \mathrm{g}$ at the top level by crested wheatgrass. The 3-day absorption period produced no indication of tracer absorption among the six grasses but the two wildryes indicated weak absorption at 17 days.

Fall 1970.- ${ }^{51} \mathrm{Cr}$ proved ineffective as a tracer in the fall trials in $\mathbf{1 9 7 0 .}$ Each tracer had 80 opportunities. ${ }^{51} \mathrm{Cr}$ was translocated to sampled shoots only 4 times as compared to 38 for ${ }^{75} \mathrm{Se}$. The chances accrued from numbers of holes $x$ species $X$
Table 5. Number of positions at which tracers were detected in June and September 1968 after different absorption periods, and the summed activity of shoot samples in $\mathrm{cpm} / \mathrm{g}$ (in parentheses).

\begin{tabular}{|c|c|c|c|c|c|}
\hline \multirow{2}{*}{$\begin{array}{l}\text { Absorption } \\
\text { period } \\
\text { (hr) }\end{array}$} & \multirow[b]{2}{*}{ Month } & \multirow{2}{*}{$\begin{array}{l}\text { Number of } \\
\text { samples }\end{array}$} & \multicolumn{3}{|c|}{ Level in capillary zone } \\
\hline & & & Top & Middle & Bottom \\
\hline 6 & June & 7 & 3 & 6 & 4 \\
\hline 24 & June & 7 & $7(69)$ & $7(38)$ & $5(28)$ \\
\hline 48 & June & 7 & 6 & 5 & 4 \\
\hline 24 & September & 11 & $10(61)$ & $10(184)$ & $6(69)$ \\
\hline 48 & September & 11 & 6 & 7 & 5 \\
\hline
\end{tabular}

Table 6. Relative absorption of isotopes by each species from three levels in the capillary zone, September 1968 .

\begin{tabular}{lrcc}
\hline \hline & \multicolumn{3}{c}{ Levels } \\
\cline { 2 - 4 } \multicolumn{1}{c}{ Species } & Top & \multicolumn{3}{c}{ Middlc Bottom } \\
\hline $\begin{array}{l}\text { Desert } \\
\text { whcatgrass }\end{array}$ & 6 & 3 & 2 \\
$\begin{array}{l}\text { Siberian } \\
\quad \text { wheatgrass }\end{array}$ & 7 & 3 & 3 \\
Pubescent & & & \\
$\quad$ wheatgrass & 11 & 3 & 0 \\
Basin wildrye & 15 & 7 & 6 \\
Russian wildrye & 15 & 5 & 6 \\
Big sagebrush & 15 & 14 & 4 \\
Poverty weed & 4 & 5 & 4 \\
\hline
\end{tabular}

absorption periods. Desert wheatgrass absorbed ${ }^{51} \mathrm{Cr}$ at all levels and it was the sole species to indicate ${ }^{51} \mathrm{Cr}$ absorption.

As the overall activity after the ll-week absorption period averaged $8.5 \mathrm{cpm} / \mathrm{g}$ as compared to $8.6 \mathrm{cpm} /$ $\mathrm{g}$ after 3 days, there appeared to be no advantage for the delay in sampling so late in the fall. Further, the number of active samples declined from 25 after 3 days to 17 after 11 weeks absorption.

Six grasses, poverty weed, and Asiatic whitesage (Eurotia ceratoides) picked up the tracers. The highest activity arose from ${ }^{75} \mathrm{Se}$ at 55 inches in the bottom of the capillary zone tapped by intermediate wheatgrass (Agropyron intermedium). Poverty weed picked up $109 \mathrm{cpm} / \mathrm{g}$ at $6 \frac{1}{2}$ feet, midway in the capillary zone. Crested, desert and Siberian wheatgrass absorbed repeatedly from all levels. Desert wheatgrass shoots analyzed 120 $\mathrm{cpm} / \mathrm{g}$ after three days absorption from $11 \frac{1}{2}$ feet, while the maximum depth by Siberian wheatgrass was $7 \frac{1}{2}$ feet at the same location. However, Siberian wheatgrass brought the tracer up from 12 feet during the 11-week period.

\section{Conclusions}

In viewing the results, it is seen that many trials yielded no positive data, and that 6 grasses, 2 shrubs 
Table 7. Maximum radioactivities during spring and fall, 1968 and 1970, of each species at each level of absorption, top, middle and bottom of the capillary zone. Activities in counts/minute/gram (cpm/g) and depth in feet.

\begin{tabular}{|c|c|c|c|c|c|c|c|c|c|c|c|c|}
\hline \multirow[b]{3}{*}{ Species } & \multicolumn{6}{|c|}{ Spring } & \multicolumn{6}{|c|}{ Fall } \\
\hline & \multicolumn{2}{|c|}{ Top } & \multicolumn{2}{|c|}{ Middle } & \multicolumn{2}{|c|}{ Bottom } & \multicolumn{2}{|c|}{ Top } & \multicolumn{2}{|c|}{ Middle } & \multicolumn{2}{|c|}{ Bottom } \\
\hline & Act. & Depth & Act. & Depth & Act. & Depth & Act. & Depth & Act. & Depth & Act. & Depth \\
\hline Crested wheatgrass & 2 & 2.3 & 11 & 2.9 & 8 & 3.6 & 10 & 2.3 & 6 & 4.3 & 9 & 6.5 \\
\hline Desert wheatgrass & 35 & 1.3 & 109 & 3.8 & 6 & 5.0 & $373^{1}$ & 2.2 & 10 & 4.4 & 23 & 6.7 \\
\hline Siberian wheatgrass & 6 & 2.5 & 7 & 3.8 & 5 & 5.0 & 5 & 1.8 & 32 & 5.0 & 6 & 4.9 \\
\hline Pubescent wheatgrass & 113 & 3.1 & 12 & 4.8 & 4 & 3.2 & 11 & 1.9 & 38 & 4.3 & 3 & 6.5 \\
\hline Basin wildrye ${ }^{2}$ & 52 & 2.7 & 226 & 3.5 & 48 & 4.5 & 8 & 1.8 & 25 & 3.3 & 13 & 6.1 \\
\hline Russian wildrye & 13 & 2.7 & 16 & 3.5 & 4 & 5.3 & - & - & 2 & 4.8 & 8 & 4.8 \\
\hline Canada vetch ${ }^{2}$ & 151 & 1.3 & 200 & 2.2 & 67 & 3.2 & - & - & - & - & - & - \\
\hline Poverty weed $^{2}$ & 9 & 1.4 & 17 & 2.8 & 3 & 4.3 & 13 & 2.2 & 109 & 4.9 & 15 & 6.7 \\
\hline Big sagebrush ${ }^{2}$ & - & - & - & - & - & - & 50 & 3.8 & 34 & 5.0 & 14 & 6.1 \\
\hline Asiatic whitcsage & - & - & - & - & - & - & 2 & 2.5 & 5 & 4.8 & 4 & 6.7 \\
\hline Grasses, mean & 37 & & 64 & & 12 & & 8 & & 19 & & 10 & \\
\hline
\end{tabular}

1 Omitted from average.

${ }^{2}$ Residual native species.

and a forb absorbed repeatedly from different depths. Table 7 contains the highest reading in $\mathrm{cpm} / \mathrm{g}$ shown at anytime, spring or fall, at each depth by each species. These data are presented as the best indication available of absorptive ability. Only the maxima wcre sclected for Table 7 because they are believed to afford a better indication of root activity than the various lower readings. The zero and low readings may result from unfortunate placing of the tracer, or failure to include the most active shoot in the sample.

Evidently absorption was slightly more rapid in spring than fall, excepting at the water line, where it was alike in both seasons. Absorption was clearly more rapid from the middle than from top or bottom of the capillary moisture.

The tracer method is less laborious than direct inspection in trenches. Further, it allows for determination of absorption by several species in mixed stands thereby yielding more information per observation site.

Desert wheatgrass, basin wildrye, poverty weed and big sagebrush appeared to absorb more isotope between 6 and 7 feet than did the other species. Where sagebrush and poverty weed are phreatic, desert wheatgrass and basin wildrye should be well-adapted grasses to replace them.

Big sagebrush has not been classed as a phreatophyte. These results show that it behaves as a water waster when favored by a high watertable without rootrestricting soil. They also suggest a reason for the success of desert wheatgrass when substituted for phreatic sagebrush.

\section{Literature Cited}

Bonner, James, and A. W. Galston. 1952. Principles of plant physiology.

W. H. Freeman and Co. 169 p.

Burton, G. W., E. H. DeVane, and R. I. Ciarter. 1954. Root penetration, distribution and activity in southern grasses measured by yields, drought symptoms and $\mathbf{P}^{32}$ uptake. Agron. Jour. 46:229-233.

ECKERT, R. E. JR., AND C. R. BLINCOE. 1970. Radioisotope uptake by selected range forage and weed species. J. Range Manage. 23:367-369.

Mathis, G. W., C. C. Jaynes, and G. W. Thomas. 1965. Root development of plains bristlegrass as measured by soil placement of radiophosphorus. J. Range Manage. 18: 30-33.

Nedrow, W. W. 1937. Studies on the ecology of roots. Ecology 18: 27-52.

Pavlychenko, T. 1942 . Root systems of certain forage crops in relation to the management of agricultural soils, N. R. C. No. 1088 . Nat. Res. Council of Canada.

Price, Keith R. 1965. A field method for studying root systems. Health Physics. 11:1521-1525.

Weaver, J. E. 1926. Root development of field crops. McGraw-Hill Book Co. p. 55-58.

Woods, Frank A. 1969. Injecting solutions into soils. Tree Planters Notes 20:17-19.

\section{Specialists in Quality NATIVE GRASSES}

Wheatgrasses • Bluestems • Gramas • Switchgrasses - Lovegrasses • Buffalo • and Many Others

We grow, harvest, process these seeds Native Grasses Harvested in ten States

Your Inquiries Appreciated 